\title{
Comparative Study of Magnetic, Electric and Botanical Seed Treatment on Seedling Characters of Desi and Kabuli Chickpea (Cicer arietinum L.) Seeds
}

\author{
Kursinga Mamatha ${ }^{1}$, Prashant Kumar Rai ${ }^{1}$, Sarita Khandka ${ }^{2}$, \\ Bazil Avinash Singh $^{1}$ and Seragadam Sivaji ${ }^{*}$
}

${ }^{1}$ Department of Genetics and Plant Breeding, Naini Agricultural Institute, Sam Higginbottom University of Agriculture, Technology and Sciences, Prayagraj, Uttar Pradesh, 211007, India

${ }^{2}$ Department of Physics, Sam Higginbottom University of Agriculture, Technology and

Sciences, Prayagraj, Uttar Pradesh, 211007, India

${ }^{3}$ Department of Agronomy, Sam Higginbottom University of Agriculture, Technology and

Sciences, Prayagraj, Uttar Pradesh, 211007, India

*Corresponding author

\section{A B S T R A C T}

The present investigation was conducted to study the "Comparative study of magnetic, electric and botanical seed priming on seedling characters of Desi and

Keywords

Magnetic priming,

Electric priming,

Botanical priming,

Chickpea, Desi,

Kabuli

Article Info

Accepted:

10 July 2019

Available Online:

10 August 2019 kabuli Chickpea (Cicer arietinum L.) seeds." at post graduate laboratory of Seed Science at Department of Genetics and Plant Breeding, Naini Agricultural Institute, Sam Higginbottom University of Agriculture, Technology and Sciences, Prayagraj (U.P). The experiment comprised of nine treatments each for Desi and Kabuli variety in Completely Randomized Design (CRD) with three replications. Analysis of variance showed significant difference among the priming treatments for the characters studied in the chickpea which indicates significant effect of the priming on the germination and seedling parameters of the crop. Electric priming @ 1.0 A for 60 seconds [T5] recorded significantly higher values for seedling characters, viz., shoot length, Root length, Seedling fresh weight, dry weight and Seedling vigour index-I in both Desi and Kabuli chickpea. This is found to be statistically at par with T4 (0.5A for 60 seconds) in case of Desi variety whereas, T8 (Neem leaf extract priming) is statistically at par in Kabuli variety.

\section{Introduction}

Chickpea (Cicer arietinum L.) is the third most important cool season food legume in the world after dry beans and peas (FAOSTAT, 2017). Chickpea is a diploid with $2 n=2 x=16$ (Arumuganathan and Earle, 1991) having a genome size of approximately $931 \mathrm{Mbp}$. Chickpea is a self-pollinated crop. Crosspollination is rare; only $0-1 \%$ is reported (Reddy, 2003).

The genus Cicer belongs to the family Leguminosae, subfamily Papilionoideae, tribe 
Cicereae Alef and comprises 43 species, nine of which being annual including Chickpea, while the rest are perennial (Van der Maesen, 1987). Chickpea is currently cultivated in over 40 countries worldwide and grown on 11 million hectares producing around 12.1 million tonnes in 2016 growing season (FAOSTAT, 2017). Two main types of chickpea cultivars are grown globally- kabuli and desi representing two diverse gene pools.

Exposure of seeds to electromagnetic fields is one of the safest and potential physical presowing treatments to enhance the post germination development and crop stand (Florez et al., 2007). Magnetic field is especially worth our attention since its impact on the seeds can change the processes taking place in the seed and stimulate plant development. Nilimesh (2014) reported that speed of germination and seedling growth of Chickpea (Cicer arietinum L.) were affected by pre germination exposure of the dry seed to an introduced magnetic field.

Pre-germination exposure to static magnetic field of wheat seeds (cv. Sonalika) increased the rate of germination, shoot length, maximum root length and total root length significantly (Bhatnagar and Deb, 1977). Similar effect has been reported in flax, buckwheat, sunflower and field pea (Gubbels, 1982) and ragi (Kavi, 1983).

Botanical seed treatment is derived from natural sources based on botanical ingredient. It is liquid, natural seed treatment and root growth promoter formulation. It also stimulates indigenous microbes in the root zone. It is proven to be a reliable performer in low and high rainfall areas and in all soil types. It is an affordable and effective way to optimize early growth and yield potential. It is also one of the lowest financial investments through which a grower can make to maximize productivity and improve the bottom line. Seed priming is a common practice followed to improve seed performance with respect to uniformity of germination and rate of germination (De Lespinay et al., 2010). Seed priming is the process of regulating germination by managing the temperature and seed moisture content, in order to maximize the seed's potential. Hence the present study was undertaken to evaluate the various seed priming treatments on growth and yield characters of Chickpea (Cicer arietinum L.).

\section{Materials and Methods}

The experiment was carried out in the Post Graduate Laboratory, Department of Genetics and Plant Breeding, Naini Agricultural Institute, Sam Higginbottom University of Agriculture, Technology and Sciences, Prayagraj (U.P.) India. The Crop Research Farm is situated at $25^{\circ} 57^{\prime} \mathrm{N}$ Latitude, $87^{\circ} 50^{\prime}$ E longitude and 98 meter altitude above the MSL. This area is situated on the right side of the river Yamuna and opposite side of Prayagraj city.

The experiment was laid out in Complete Randomized Design (CRD) with 9 treatments each of desi and kabli variety in three replications. Treatments consisted of three levels of magnetic treatment (400 Gauss for 15 minutes, 400 Gauss for 30 minutes and 400 Gauss for 45 minutes) three levels of electric treatment $(0.5 \mathrm{~A}$ for 60 seconds, $1.0 \mathrm{~A}$ for 60 seconds and $1.5 \mathrm{~A}$ for 60 seconds) and two botanical seed treatments (Neem leaf extract and tulsi leaf extract).

\section{Results and Discussion}

\section{Germination \%}

In desi variety, highest Germination \% was found in T4 (Electric priming @ 0.5 A for 60 seconds) followed by T5 (Electric priming @ 
1.0 A for 60 seconds), whereas minimum was observed in T0 - control (hydroprimed).

In kabuli variety, highest Germination \% was found in T8 (Soaked in Neem leaf extract overnight) followed by $\mathrm{T} 5$ (Electric priming @ 1.0A for 60 seconds), whereas minimum was observed in T0 - control (hydroprimed). These findings are in collaboration with shivani singh et al., (2017) (Table 1 and 2).

\section{Speed of germination}

In Desi variety, highest Speed of germination was found in T4 (Electric priming @ 0.5A for 60 seconds) followed by T5 (Electric priming @ 1.0A for 60 seconds), whereas minimum was observed in T0 - control (hydroprimed).

In Kabuli variety, highest Speed of germination was found in T8 (Soaked in Neem leaf extract overnight) followed by T5 (Electric priming @ 1.0A for 60 seconds), whereas minimum was observed in T0 control (hydroprimed).

This may be due to the acelerated germination of primed seeds might be due to increased rate of cell division (Bose, et al., 1992) and stimulation of metabolic activiles during early phases of seed gemination. Similar research also reported reduction of mean germination time (Bocian et al., 2008), (Casenave, et al., 2007) and (Sung, et al., 1995).

\section{Shoot length}

In Desi variety, highest shoot length was found in T5 (Electric priming @ 1.0 A for 60 seconds) followed by T4 (Electric priming @ 0.5 A for 60 seconds), whereas minimum was observed in T0 - control (hydroprimed).

In Kabuli variety, highest shoot length was found in T5 (Electric priming @ 1.0 A for 60 seconds) followed by T8 (Soaked in Neem leaf extract overnight), whereas minimum was observed in T0 - control (hydroprimed). Increased shoot and root length may be due to triggered reaction induced by priming treatment as compared to unprimed seeds. Stofella et al., (1992) presented the same results by observing that priming of the pepper seeds significantly improved root and shoot length.

\section{Seedling fresh weight}

In Desi variety, highest Seedling Fresh weight was found in T5 (Electric priming @ 1.0 A for 60 seconds) followed by T4 (Electric priming @ $0.5 \mathrm{~A}$ for 60 seconds), whereas minimum was observed in T0 - control (hydroprimed). In Kabuli variety, highest Seedling Fresh weight was found in T5 (Electric priming @ 1.0 A for 60 seconds) followed by T8 (Soaked in Neem leaf extract overnight), whereas minimum was observed in T0 - control (hydroprimed).

It may be due to the higher shoot, root and seedling length and healthy seedling. As the root, shoot and seedling length increases seedling fresh weight may increase. Increase in Shoot length and root length may lead to higher fresh weight. Stofella et al., (1992) presented the same results by observing that priming of the pepper seeds significantly improved root and shoot length.

\section{Dry weight}

In Desi variety, highest Seedling Dry weight was found in T5 (Electric priming @ 1.0 A for 60 seconds) followed by T4 (Electric priming @ 0.5 A for 60 seconds), whereas minimum was observed in T0 - control (hydroprimed).In Kabuli variety, highest Seedling Dry weight was found in T5 (Electric priming @ 1.0 A for 60 seconds) followed by T8 (Soaked in Neem leaf extract overnight), whereas minimum was observed in T0 - control (hydroprimed). 
Table.1 Effect of different treatments on various seedling characters of desi chickpea

\begin{tabular}{|c|c|c|c|c|c|c|c|c|c|}
\hline Treatment & $\begin{array}{c}\text { Germination } \\
\mathbf{\%}\end{array}$ & $\begin{array}{c}\text { Speed of } \\
\text { germination }\end{array}$ & $\begin{array}{c}\text { Shoot } \\
\text { length } \\
\text { (cm) }\end{array}$ & $\begin{array}{c}\text { Root } \\
\text { length } \\
\text { (cm) }\end{array}$ & $\begin{array}{c}\text { Seedling } \\
\text { length } \\
\text { (cm) }\end{array}$ & $\begin{array}{c}\text { Seedling } \\
\text { fresh wt } \\
\text { (mg) }\end{array}$ & $\begin{array}{c}\text { Seedling } \\
\text { Dry wt } \\
\text { (mg) }\end{array}$ & $\begin{array}{c}\text { Vigour } \\
\text { index }- \text { I }\end{array}$ & $\begin{array}{c}\text { Vigour } \\
\text { index - } \\
\text { II }\end{array}$ \\
\hline T0 & 65.3 & 66.93 & 12.82 & 9.36 & 24.50 & 0.663 & 0.104 & 1665.3 & 6.81 \\
\hline T1 & 77.3 & 73.51 & 16.11 & 14.02 & 29.42 & 1.003 & 0.114 & 2605.3 & 8.85 \\
\hline T2 & 75.6 & 72.51 & 17.06 & 14.15 & 30.02 & 1.033 & 0.133 & 2456.7 & 10.10 \\
\hline T3 & 74.33 & 71.43 & 15.70 & 13.23 & 28.40 & 0.910 & 0.095 & 2225.3 & 7.12 \\
\hline T4 & 87.0 & 77.11 & 18.26 & 15.04 & 32.93 & 1.118 & 0.125 & 3026.1 & 10.88 \\
\hline T5 & 80.0 & 75.37 & 20.33 & 16.14 & 34.92 & 1.200 & 0.147 & 2833.8 & 11.76 \\
\hline T6 & 69.0 & 67.34 & 13.11 & 9.89 & 25.82 & 0.682 & 0.115 & 1772.4 & 7.94 \\
\hline T7 & 67.3 & 67.27 & 13.68 & 10.33 & 26.44 & 0.733 & 0.139 & 1833.5 & 9.42 \\
\hline T8 & 71.0 & 70.57 & 14.80 & 12.63 & 27.58 & 0.863 & 0.184 & 2030.5 & 13.09 \\
\hline G mean & $\mathbf{7 4 . 0 9}$ & $\mathbf{7 1 . 3 3}$ & $\mathbf{1 5 . 7 6}$ & $\mathbf{1 2 . 7 5}$ & $\mathbf{2 8 . 8 9}$ & $\mathbf{0 . 9 1 1}$ & $\mathbf{0 . 1 2 8}$ & $\mathbf{2 2 7 2 . 1}$ & $\mathbf{9 . 5 5}$ \\
\hline CD @ 5\% & 4.97 & 5.01 & 1.65 & 1.21 & 1.63 & 0.0175 & 0.054 & 124.2 & 1.01 \\
\hline
\end{tabular}

Table.2 Effect of different treatments on various seedling characters of Kabuli chickpea

\begin{tabular}{|c|c|c|c|c|c|c|c|c|c|}
\hline Treatment & $\begin{array}{c}\text { Germination } \\
\text { \% }\end{array}$ & $\begin{array}{c}\text { Speed of } \\
\text { germination }\end{array}$ & $\begin{array}{c}\text { Shoot } \\
\text { length } \\
\text { (cm) }\end{array}$ & $\begin{array}{c}\text { Root } \\
\text { length } \\
\text { (cm) }\end{array}$ & $\begin{array}{c}\text { Seedling } \\
\text { length } \\
\text { (cm) }\end{array}$ & $\begin{array}{c}\text { Seedling } \\
\text { fresh wt } \\
\text { (mg) }\end{array}$ & $\begin{array}{c}\text { Seedling } \\
\text { Dry wt } \\
\text { (mg) }\end{array}$ & $\begin{array}{c}\text { Vigour } \\
\text { index }- \text { I }\end{array}$ & $\begin{array}{c}\text { Vigour } \\
\text { index }- \text { II }\end{array}$ \\
\hline T0 & 64.05 & 65.68 & 12.31 & 9.19 & 21.50 & 0.660 & 0.109 & 1374.1 & 7.02 \\
\hline T1 & 69.97 & 70.94 & 15.27 & 13.28 & 28.55 & 0.930 & 0.123 & 2101.5 & 8.63 \\
\hline T2 & 75.00 & 71.56 & 16.95 & 14.18 & 31.13 & 1.080 & 0.132 & 2250.1 & 9.75 \\
\hline T3 & 66.49 & 68.48 & 15.61 & 12.65 & 28.26 & 0.880 & 0.120 & 1880.8 & 8.03 \\
\hline T4 & 76.38 & 71.88 & 15.99 & 14.05 & 30.02 & 1.020 & 0.135 & 2372.3 & 10.34 \\
\hline T5 & 81.92 & 74.05 & 20.59 & 16.45 & 37.04 & 1.620 & 0.135 & 2703.1 & 11.07 \\
\hline T6 & 68.24 & 69.36 & 14.46 & 11.28 & 24.91 & 0.720 & 0.120 & 1997.7 & 8.19 \\
\hline T7 & 72.22 & 71.17 & 15.98 & 13.33 & 29.32 & 1.010 & 0.132 & 2117.7 & 9.60 \\
\hline T8 & 85.00 & 75.94 & 17.94 & 15.05 & 33.00 & 1.110 & 0.148 & 3119.7 & 12.63 \\
\hline G mean & $\mathbf{7 3 . 2 5}$ & $\mathbf{7 1 . 0 0}$ & $\mathbf{1 6 . 1 2}$ & $\mathbf{1 3 . 2 7}$ & $\mathbf{2 9 . 3 0}$ & 1.003 & $\mathbf{0 . 1 2 8}$ & $\mathbf{2 2 1 3}$ & $\mathbf{9 . 4 7}$ \\
\hline CD @ 5\% & 3.4 & 4.44 & 0.81 & 0.39 & 1.07 & 0.031 & 0.04 & 138.2 & 2.902 \\
\hline
\end{tabular}

This result might be due to an increase of the synthesis of the hormone gibberellin, which Triggers the activity of alpha-amylase and other germination specific enzymes like protease and nuclease involved in hydrolysis and assimilation of the starch (Gholami et al., 2009).

The present investigation was conducted to study the "Comparative study of magnetic, electric and botanical seed priming on seedling characters of Desi and kabuli Chickpea (Cicer arietinum L.) seeds." at post graduate laboratory of Seed Science at Department of Genetics and Plant Breeding, Naini Agricultural Institute, Sam Higginbottom University of Agriculture, Technology and Sciences, Prayagraj (U.P).

The experiment comprised of nine treatments each for Desi and Kabuli variety in 
Completely Randomized Design (CRD) with three replications.

Analysis of variance showed significant difference among the priming treatments for the characters studied in the chickpea which indicates significant effect of the priming on the germination and seedling parameters of the crop.

Electric priming @ 1.0 A for 60 seconds [T5] recorded significantly higher values for seedling characters, viz., shoot length, Root length,

Seedling fresh weight, dry weight and Seedling vigour index -I in both Desi and Kabuli chickpea.

This is found to be statistically at par with T4 ( $0.5 \mathrm{~A}$ for 60 seconds) in case of Desi variety whereas, T8 (Neem leaf extract priming) is statistically at par in Kabuli variety.

It is concluded from the present investigation that the seeds of Chickpea were treated with different types of priming showed significant effect on various seedling characters.

T5 [Electric priming @ 1.0A for 60 seconds] showed significant effect on Shoot length, root length, seedling fresh weigh and dry weight in chickpea (both Desi and Kabuli) seeds.

Since the data obtained in the experiment is of one year. Therefore, the experiment needs to be repeated to confirm the findings.

\section{References}

Amarnath, B. H., Chaurasia A.K., Arvind K. (2013). Effect of priming with botanicals and animal waste on germination and seedling vigour in sorghum (Sorghum bicolor L.) seeds.
Advances in Applied Science Research, 2015, 6(10): 73-77.

Deepti, P., Negi, S. (2015). Effect of seed priming with some plant leaf extract on seedling growth characteristics and root rot disease in tomato. International Journal of Agriculture System (IJAS). 4(1):132-135.

Food and Agriculture Organization of the United Nations (FAOSTAT), 2017. Available at http:// faostat.fao.org/

James, B., Rai, P.K. (2018). Influence of different priming treatments on seedling parameters of chickpea (Cicer arietinum L.) seeds. International Journal of Chemical Studies 2018; 6(4): 17931796.

Jyothi, G.B.N., Rai, P.K. (2017). Effect of magnetic and electric field seed treatment on the seedling attributes of brinjal (Solanum melongena) seeds. International Journal of Chemical Studies 2018; 6(5): 2780-2784.

Nawroz, A.R.T., Karim, F, H. (2010). Impact of magnetic application on the parameters related to growth of chickpea (Cicer arietinum L.). Jordan Journal of Biological Sciences. 2010. ISSN 1995-6673 3(4):175- 184.

Nilimesh, M., Shanta N. (2014). Effect of presowing static magnetic seed treatment on germination and root characters in chickpea (Cicer arietinum L.) Journal of Agricultural Physics ISSN 0973032X 14(1): 22-29.

Nisar, K., Sangma, K. and Singh Rani, (2013). Effect of electric treatment on germination, seedling growth and water uptake in chickpea seed. African Journal of Agronomy. ISSN 2375-1177 Vol. 6 (5): 383-392.

Pietruszewski, S. and Martinez, E. (2015). Magnetic field as a method of improving the quality of sowing material: a review. International journal of Agrophysics. 29: 377-389. 
Podlesny, J., Pietruszewski, S. and Podlesna, A. (2005). Influence of magnetic stimulation of seeds on the formation of morphological features and yielding of the pea.International journal of Agrophysics. 19: 1-8.

Rajendra, P., Nayak, H.S., Sashidhar, R.B., Subramanyam, C., Devendarnath, D., Gunasekaran, B., Aradhya, R.S.S. and Bhaskaran, A. (2005). Effects of power frequency electromagnetic fields on growth of germinating vicia faba L., the broad bean. Journal of Eletromagnetic Biology and Medicine 24: 39-54.

Rotcharoen, T., Khan-ngern, W. and Nitta, S. (2002). The effect of electric field to rice plant growing. ICEMC, Bangkok. Saebo, A., Krekling, T. and Appelgren, M. (1995). Light quality affects photosynthesis and leaf anatomy of brich plantlets in vitro. Journal of Plant
Cell and Tissue Organisation. 41: 177185.

Singh, S. and Chaurasia, A.K. (2017). Effects of hardening methods on seedling characters, germination and nodulation in greengram. Internationl Journal of Current Microbiology Applications and Sciences. 6(9): 2297-2303.

Vashisth, A. and Nagarajan, S. (2008a). Effect of magnetic field on seed performance of diverse crop species. Indian Journal of Agricultural Sciences 78: 708-711.

Vashisth, A. and Nagarajan, S. (2008b). Exposure of seeds to static magnetic field enhances germination and early growth characters in chickpea (Cicer arietinum L.). Journal of Bioelectromagnetics. 29: 571-578.

\section{How to cite this article:}

Kursinga Mamatha, Prashant Kumar Rai, Sarita Khandka, Bazil Avinash Singh and Seragadam Sivaji. 2019. Comparative Study of Magnetic, Electric and Botanical Seed Treatment on Seedling Characters of Desi and Kabuli Chickpea (Cicer arietinum L.) Seeds. Int.J.Curr.Microbiol.App.Sci. 8(08): 998-1003. doi: https://doi.org/10.20546/ijcmas.2019.808.115 